\title{
Genetic variability of age and weight at puberty, ovulation rate and embryo survival in gilts and relations with production traits
}

\author{
JP Bidanel ${ }^{1}, \mathrm{~J}_{\text {Gruand }}{ }^{2}$, C Legault ${ }^{1}$
}

1 Station de génétique quantitative et appliquée, Centre de recherche de Jouy-en-Josas, Institut national de la recherche agronomique, 78352 Jouy-en-Josas cedex;

2 Station expérimentale de sélection porcine, Institut national de la recherche agronomique, 86480 Rouillé, France

(Received 12 January 1995; accepted 21 September 1995)

Summary - Age (AFE), weight (WFE) and ovulation rate (OR) at first estrus, number of embryos $(\mathrm{NE})$ and embryo survival $(\mathrm{ES}=\mathrm{NE} / \mathrm{OR})$ at 30 days of gestation of French Large White (LW), French Landrace (LF) and crossbred LW $\times$ LF gilts and their genetic relationships with average daily gain between 30 and $85 \mathrm{~kg}$ (ADG) and average backfat thickness at $85 \mathrm{~kg}(\mathrm{ABT})$ were analyzed. Breed differences, as well as genetic parameters in the LW breed, were estimated using a restricted maximum likelihood procedure applied to a multiple trait animal model. A total of 3664 male and female pigs were measured for ADG and ABT between 1966 and 1979; 1919 gilts were checked daily for puberty between 140 and 300 days of age. Most females were then bred and slaughtered at 30 days of gestation for measuring the number of corpora lutea and the number of embryos. Breed marginal means were, respectively, $214.9 \pm 1.4,197.8 \pm 3.3$ and $190.1 \pm 2.1$ days for AFE, $116.1 \pm 0.9,102.5 \pm 2.2$ and $97.7 \pm 1.4 \mathrm{~kg}$ for WFE, $14.4 \pm 0.1,13.0 \pm 0.3$ and $13.9 \pm 0.2$ for OR and $9.6 \pm 0.1,9.6 \pm 0.4$ and $10.5 \pm 0.3$ for $\mathrm{NE}$ in $\mathrm{LW}, \mathrm{LF}$ and $\mathrm{LW} \times \mathrm{LF}$ gilts. Heritability estimates were $0.29,0.51,0.27,0.14$ and 0.08 (se 0.03 ), respectively, for AFE, WFE, OR, NE and ES. Genetic correlations between AFE and WFE, between NE and OR or ES were rather large $(0.84 \pm 0.05,0.73 \pm 0.12$ and $0.79 \pm 0.15$ respectively). OR and ES had a low genetic correlation $(-0.11 \pm 0.15)$. AFE was negatively correlated with ADG $(-0.18 \pm 0.05), \operatorname{ABT}(-0.21 \pm 0.05)$, OR $(-0.36 \pm 0.09)$ and NE $(-0.35 \pm 0.08)$. WFE also tended to be negatively correlated with OR $(-0.26 \pm 0.11)$ and $\mathrm{NE}(-0.18 \pm 0.10)$, but exhibited low or positive genetic correlations with $\mathrm{ABT}(0.08 \pm 0.05)$ and ADG $(0.34 \pm 0.05)$. OR, NE and ES had low or favourable genetic correlations with both ADG and $\mathrm{ABT}$.

pig / genetic parameter / puberty / production trait / reproduction trait 
Résumé - Variabilité génétique de l'âge et du poids à la puberté, du taux d'ovulation et de la mortalité embryonnaire chez la cochette. Relations avec les caractères de production et de reproduction. L'âge (APO), le poids (PPO) et le taux d'ovulation (TO) au premier ostrus, le nombre d'embryons (NE) et la survie embryonnaire $(E S=N E / T O)$ $\grave{a} 30$ jours de gestation de cochettes Large White $(L W)$, Landrace Français $(L F)$ et croisées $L W \times L F$, ainsi que leurs relations avec le gain moyen quotidien entre 30 et $85 \mathrm{~kg}$ (GMQ) et l'épaisseur moyenne de lard dorsal à $85 \mathrm{~kg}$ ont été analysés. Les différences entre races, ainsi que les paramètres génétiques de la race $L W$, ont été estimés à l'aide d'une procédure du maximum de vraisemblance restreinte appliquée à un modèle animal multicaractère. Un total de 3664 porcs mâles et femelles ont été mesurés pour GMQ et ELD entre 1966 et 1979. Un contrôle quotidien de la puberté a été réalisé entre 140 et 300 jours d'âge sur un total de 1919 cochettes. La plupart des femelles ont ensuite été mises à la reproduction et abattues à 30 jours de gestation afin de mesurer TO et NE. Les moyennes marginales s'élèvent à, respectivement, 214,9 $\pm 1,4 ; 197,8 \pm 3,3$ et 190,1 $\pm 2,1$ jours d'âge pour $A P O, 116,1 \pm 0,9 ; 102,5 \pm 2,2$ et $97,7 \pm 1,4 \mathrm{~kg}$ pour $P P O, 14,4 \pm 0,1 ; 13,0 \pm 0,3$ et $13,9 \pm 0,2$ pour TO et 9,6 $\pm 0,1 ; 9,6 \pm 0,4$ et 10,5 $\pm 0,3$ pour $N E$ chez les cochettes $L W$, $L F$ et $L W \times L F$. Les estimations de l'héritabilité s'élèvent à 0,$29 ; 0,51 ; 0,27 ; 0,14$ et 0,08 (es 0,03), respectivement, pour APO, PPO, TO, NE et SE. Les corrélations génétiques entre $A P O$ et $P P O$, ainsi qu'entre $N E$ et TO ou $S E$, sont élevées (respectivement $0,84 \pm$ $0,05 ; 0,73 \pm 0,12$ et $0,79 \pm 0,15)$. TO et ES sont faiblement corrélés $(-0,11 \pm 0,15)$. APO est négativement corrélé à $G M Q(-0,18 \pm 0,05), E L D(-0,21 \pm 0,05), T O(-0,36 \pm 0,11)$ et $N E(-0,35 \pm 0,08)$. PPO tend également à présenter des corrélations négatives avec TO $(-0,26 \pm 0,11)$ et $N E(-0,18 \pm 0,10)$, mais présente des corrélations génétiques faibles ou positives avec ELD $(0,08 \pm 0,05)$ et $G M Q(0,34 \pm 0,05)$. TO, NE et SE présentent des corrélations génétiques faibles ou favorables avec GMQ et ELD.

porc / paramètre génétique / puberté / caractère de production / caractère de reproduction

\section{INTRODUCTION}

Until recently, pig breeding programmes have concentrated on the improvement of growth rate, food conversion efficiency and carcass quality (Ollivier et al, 1990). Little selection effort has been devoted to reproduction traits, ie, sexual maturity, fertility and prolificacy.

Litter size at birth is the main contributor to variation in sow reproductive efficiency (Tess et al, 1983), but is poorly heritable and consequently rather difficult to improve through selection (Bolet et al, 1989). Johnson et al (1984) suggested that the rate of genetic improvement in litter size could be increased by selecting on its components, ie, ovulation rate and prenatal survival. Selection for ovulation rate in pigs has been effective, but without any significantly correlated response on litter size (Cunningham et al, 1979). Subsequent selection for litter size produced a significant increase in litter size (Lamberson et al, 1991). This tends to indicate that embryo and/or fetal survival take a prominent part in the variation of litter size at birth.

Early sexual maturity of gilts is also likely to have a beneficial influence on the economic efficiency of pig production. A delayed age at puberty increases the length of the unproductive period prior to first farrowing and complicates the management 
of batch farrowing systems (Tess et al, 1983; Rydhmer, 1993). Moreover, early puberty may improve genetic progress by shortening the generation interval (Hixon et al, 1987). The value of selecting for early puberty and/or components of litter size depends on their genetic variability and genetic relationships with other economically important traits. The aim of the present study is to estimate breed differences and genetic parameters of age and weight at first estrus, ovulation rate and embryo survival and their relationships with production traits in gilts.

\section{MATERIALS AND METHODS}

\section{Animals and data collection}

The experiment took place at the INRA experimental farm of Rouille (Vienne, France). Puberty traits were recorded on a total of 1393 Large White (LW), 110 French Landrace $(\mathrm{LF})$ and $501 \mathrm{LW} \times \mathrm{LF}(\mathrm{LW}$ sire and LF dam) gilts between 1966 and 1979. LW gilts were produced in the scope of a selection experiment for lean tissue growth rate (Ollivier, 1977, 1980). The design of the experiment, which began in 1965, is detailed by Ollivier (1977). In March of each year, all male offspring (except runt piglets) of the boars selected the previous year and of sows picked at random in a LW population of about 5000 sows located in small herds were grouped in the INRA experimental station of Rouillé (Vienne, France) and selected on their performance test results as described below. The animals originated from a large number of farms located around the INRA experimental herd, as only one or two litters were produced in each herd. Selected boars were then placed in the INRA artificial insemination (AI) center of Rouillé and their semen used on sows from the above-mentioned LW population to produce the next generation. In September of each year, daughters from these AI boars were also grouped in Rouillé to study puberty and prolificacy traits. It should be noted that LW males and females were born at different periods of time. Hence, they were either half- or full-sibs, but could not be littermates. Randomly sampled contemporary $\mathrm{LF}$ and $\mathrm{LW} \times \mathrm{LF}$ females were introduced into the herd in 1971, 1972, 1977 and 1978 to study breed differences. These females also came from a large number of small herds. Crossbred females were generally daughters from the same LW boars as LW gilts. Their dams were sometimes, but not systematically, related to the dams of LF gilts. As for males, all females (except runt piglets) from each litter produced were grouped at the INRA experimental station for performance testing.

Piglets were purchased at $20-25 \mathrm{~kg}$ live weight and allotted to pens of about ten animals in a semiopen building. They were performance tested from 30 to $80 \mathrm{~kg}$, extended to $85 \mathrm{~kg}$ from 1977 onwards. Animals were given ad libitum access to a pelleted diet in self feeders and to water during the whole test period. Then, gilts were given a daily ration of feed averaging $2.5 \mathrm{~kg}$ until slaughter. A preliminary diet formulated to contain $3.2 \mathrm{Mcal}$ and $17 \%$ crude protein $/ \mathrm{kg}$ was fed until $60 \mathrm{~kg}$ liveweight. The energy and protein contents of the diet were then reduced to 3.0 Mcal and $15 \%$ crude protein $/ \mathrm{kg}$ until slaughter.

Animals were weighed at the beginning and at the end of the test period. Backfat thickness was measured at the same time as final weight. The ultrasonic measurements were taken on each side of the spine, $4 \mathrm{~cm}$ from the mid-dorsal line 
at the levels of the shoulder, the last rib and the hip joint, respectively. LW boar candidates were selected on the basis of a performance test index:

$$
I=0.01 \mathrm{ADG}-0.5 \mathrm{ABT}
$$

where ADG is average daily gain (in g) over the test period and ABT is the average of the six backfat measurements (in $\mathrm{mm}$ ), adjusted for final weight.

Puberty was defined as the first estrus, indicated by a standing response to a teaser boar. Estrus detection on a daily basis was initiated when the heaviest gilt in a pen reached $80 \mathrm{~kg}$ (ie, at approximately 140 days of age) and continued until 300 days of age. Gilts were weighed when they reached first-detected estrus and immediately inseminated (except in 1967, 1968 and 1971). They were then slaughtered 27-30 days after reaching first estrus. Ovaries were dissected to count corpora lutea and embryo number recorded in pregnant females. Females that did not conceive were not bred again. The ovulation rate of gilts which did not conceive at the first estrus records were measured at the second estrus and were excluded from the analysis. Similarly, reproductive measurements from gilts ovulating without any detectable estrus symptoms and from gilts showing estrus symptoms without ovulation were discarded from the appropriate data vectors. Conversely, puberty and ovulation rate records from gilts born in 1967, 1968 and 1971, which were not inseminated but were slaughtered 7-13 days after puberty, were retained in the analyzes.

Seven traits were defined and analyzed from the above-mentioned measurements, ie, ADG, ABT, age (AFE) and weight (WFE) at first detectable estrus, ovulation rate (OR) estimated as the total number of corpora lutea, the number of living embryos (NE) at 30 days of gestation and embryo survival rate (ES) defined as the ratio of number of embryos to ovulation rate.

The structure of the data studied is shown in table I. LW ancestors were known over the experiment on the male side. Conversely, the parents of most dams and the paternal grandams were generally unknown. Part of these data were previously analyzed by Legault (1973) and Legault and Gruand (1981), but genetic parameter estimation was limited to heritabilities.

\section{Statistical analyzes}

Preliminary analyzes showed that: i) most gilts reached puberty before 300 days of age $(95,98$ and $98 \%$ of animals checked for puberty, respectively, in LW, LF and $L W \times L F$ populations); and ii) gilts ovulating without any detectable estrus symptoms and gilts showing estrus symptoms without ovulating represented less than $1 \%$ of the total number of gilts. Hence, there was almost no left or right censorship on reproductive traits. Moreover, all traits except ES were almost normally distributed, (puberty traits were only slightly skewed) so that standard mixed linear model procedures were considered adequate to analyze the data.

Genetic and environmental parameters were estimated in the LW breed using a derivative-free restricted maximum likelihood (REML) procedure applied to a multiple trait individual animal model. The data set was too large to allow a single seven-trait REML analysis. Hence, ten successive four-trait analyzes were performed. These four-trait analyzes systematically included ADG and ABT in 
Table I. Structure of the data studied.

\begin{tabular}{lccc}
\hline & $\begin{array}{c}\text { Large White } \\
(L W)\end{array}$ & $\begin{array}{c}\text { French Landrace } \\
(L F)\end{array}$ & $L W \times L F$ \\
\hline Number of records & & & \\
Growth traits & & - & - \\
$\quad$ Males & 1660 & 110 & 423 \\
$\quad$ Females & 1393 & 103 & 423 \\
Puberty traits & 1393 & 103 & 172 \\
Ovulation rate & 1111 & 76 & 31 \\
Number of embryos & 634 & 7 & 143 \\
Number of year $\times$ batches & 40 & 18 & 143 \\
Number of sires & 270 & 36 & 36 \\
Number of dams & 1178 & & \\
Number of litters & 1393 & & \\
\hline
\end{tabular}

order to account for the effects of selection, plus two reproduction traits in order to get estimates of the covariances between reproduction traits and between reproduction and production traits. The model for ADG and ABT included sex and year with batch interaction as fixed effects, with litter of birth and animal fitted as random effects. The same model, but without the sex effect, was used for $\mathrm{AFE}, \mathrm{WFE}, \mathrm{OR}, \mathrm{NE}$ and ES. The analyzes were performed using version 2.2 of the VCE computer package (Groeneveld, 1993). Approximate standard errors of variance components and genetic parameters were obtained from an approximation of the Hessian matrix when convergence was reached.

Estimates of breed marginal means were computed using BLUP (best linear unbiased prediction; Henderson, 1973) methodology applied to an individual animal model. The model was a seven-trait animal model including breed, year with batch interaction and sex (for ADG and ABT only) as fixed effects, with litter of birth and animal fitted as random effects. The PEST computer package (Groeneveld and Kovac, 1990) was used for this purpose. Genetic and environmental (co)variances used were the REML estimates obtained in the LW breed. Variance estimates from univariate REML analyzes on the whole set of data were similar to those obtained in the LW breed, thus indicating that genetic parameters did not widely differ between genetic types.

\section{RESULTS}

Genetic type marginal means are shown in table II. LW animals grew faster $(+68 \pm 12 \mathrm{~g} / \mathrm{d})$ and were fatter $(+2.6 \pm 0.3 \mathrm{~mm}$ of backfat thickness $)$ than their $\mathrm{LF}$ contemporaries. Crossbred $\mathrm{LW} \times \mathrm{LF}$ animals were intermediate (deviations from purebred means were, respectively, $+6 \pm 9 \mathrm{~g} /$ day and $+0.3 \pm 0.3 \mathrm{~mm}$, for $\mathrm{ADG}$ and $\mathrm{ABT})$. LW gilts were older $(+17.1 \pm 3.5$ days $)$ and heavier at puberty $(+13.6 \pm 1.8 \mathrm{~kg})$ than LF gilts. They also had more corpora lutea $(+1.3 \pm 0.3)$, but a lower embryo survival $(-7.1 \pm 2.7)$ than LF gilts, so that the number of embryos was similar in both breeds. Crossbred females had an earlier sexual maturity than 
both purebreds. Deviations from purebred average performance were $-16.2 \pm 2.8$ days and $-11.6 \pm 1.8 \mathrm{~kg}$, respectively, for AFE and WFE. Crossbred gilts were almost intermediate for OR, but had a better embryo survival $(5.2 \pm 2.2 \%)$ and more living embryos than purebred animals $(+0.9 \pm 0.3$ embryos).

Table II. Estimates of genetic type marginal means ( \pm se) for the traits studied.

\begin{tabular}{|c|c|c|c|}
\hline Trait & $\begin{array}{l}\text { Large White } \\
\quad(L W)\end{array}$ & $\begin{array}{l}\text { French Landrace } \\
\qquad(L F)\end{array}$ & $L W \times L F$ \\
\hline Average daily gain (ADG) (g/day) & $814 \pm 4$ & $746 \pm 12$ & $786 \pm 7$ \\
\hline Average backfat thickness (ABT) (mm) & $21.2 \pm 0.1$ & $18.6 \pm 0.3$ & $20.2 \pm 0.2$ \\
\hline Age at first estrus (AFE) (days) & $214.9 \pm 1.4$ & $197.8 \pm 3.3$ & $190.1 \pm 2.1$ \\
\hline Weight at first estrus (WFE) (kg) & $116.1 \pm 0.9$ & $102.5 \pm 2.2$ & $97.7 \pm 1.4$ \\
\hline Ovulation rate (OR) & $14.4 \pm 0.1$ & $13.0 \pm 0.3$ & $13.9 \pm 0.2$ \\
\hline Number of embryos (NE) & $9.6 \pm 0.1$ & $9.6 \pm 0.4$ & $10.5 \pm 0.3$ \\
\hline Embryo survival (ES) (\%) & $66.7 \pm 0.9$ & $73.8 \pm 2.5$ & $75.5 \pm 1.2$ \\
\hline
\end{tabular}

Several estimates of variance components were available for each trait. However, variation among estimates was very small (less than $1 \%$ between extreme values), so that the average values of heritability and common litter effect presented in table III are almost the same as estimates obtained in each individual analysis. Heritability estimates of 0.5 for ABF and WFE were higher than those for NE and ES (0.1), with intermediate heritability estimates for ADG, AFE and OR. Common environmental effects were equal to 0.1, with high and low estimates for ADG and' ES, respectively.

Table III. Estimates of phenotypic standard deviation, heritability and common litter effect in the Large White breed.

\begin{tabular}{lccc}
\hline Trait & $\begin{array}{c}\text { Phenotypic } \\
\text { standard deviation }\end{array}$ & $\begin{array}{c}\text { Heritability } \\
( \pm \text { se })\end{array}$ & $\begin{array}{c}\text { Common litter } \\
\text { effect }( \pm \text { se) }\end{array}$ \\
\hline Average daily gain (ADG) (g/day) & 115 & $0.24 \pm 0.01$ & $0.24 \pm 0.01$ \\
Average backfat thickness (ABT) (mm) & 2.85 & $0.48 \pm 0.01$ & $0.11 \pm 0.01$ \\
Age at first estrus (AFE) (days) & 30.3 & $0.29 \pm 0.02$ & $0.08 \pm 0.02$ \\
Weight at first estrus (WFE) (kg) & 20.2 & $0.51 \pm 0.02$ & $0.08 \pm 0.02$ \\
Ovulation rate (OR) & 2.61 & $0.27 \pm 0.02$ & $0.06 \pm 0.02$ \\
Number of embryos (NE) & 3.37 & $0.14 \pm 0.03$ & $0.02 \pm 0.03$ \\
Embryo survival (ES) (\%) & 21.8 & $0.08 \pm 0.03$ & $0.00^{*}$ \\
\hline
\end{tabular}

* The standard error could not be calculated as the estimate was zero.

Estimates of phenotypic and genetic correlations are shown in table IV. ADG and ABT exhibited a slightly positive, ie, unfavourable, relationship. Large positive phenotypic and genetic correlations were obtained between AFE and WFE. Similarly, NE had strongly positive genetic correlations with both OR and ES, which were poorly correlated. 


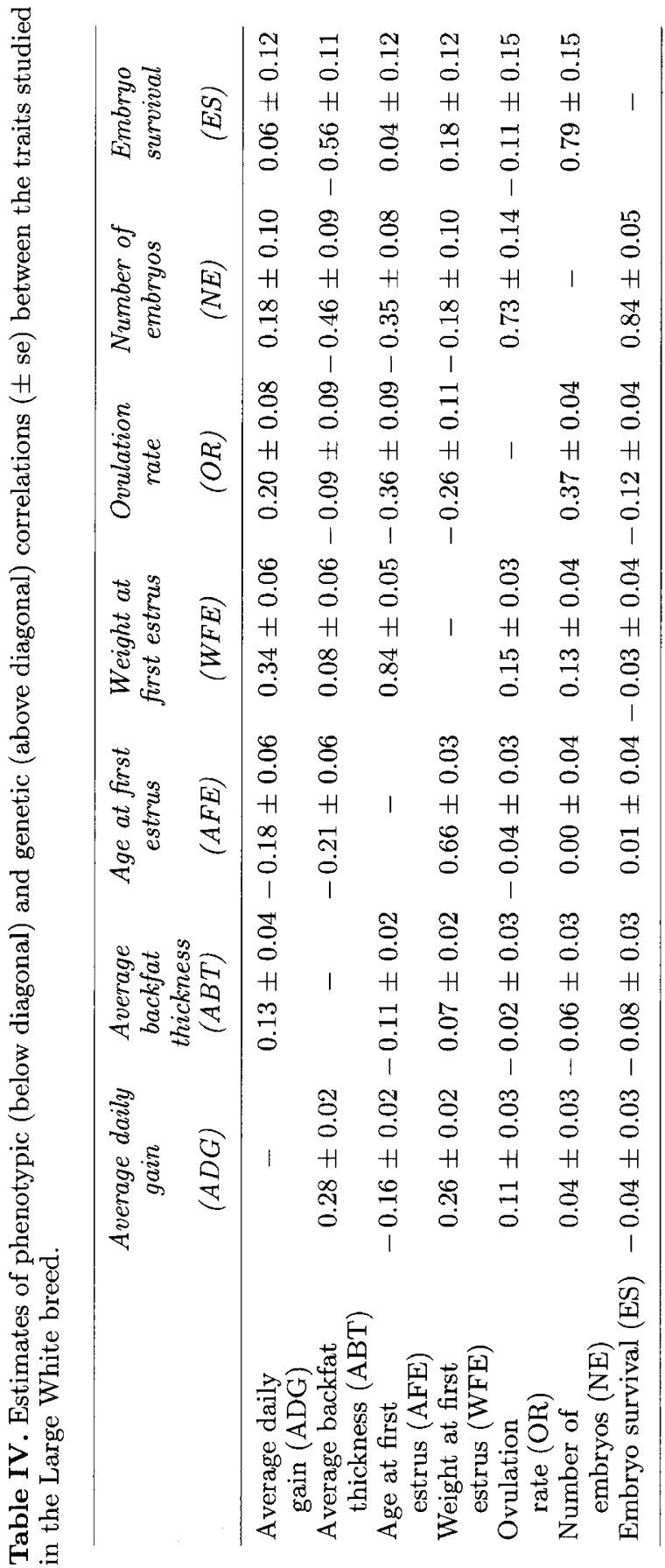


ADG was negatively, ie, favourably, correlated with AFE, but had a positive genetic correlation with WFE. Genetic correlations between ADG and prolificacy traits were low or positive, ie, favourable. ABT also tended to be favourably correlated with prolificacy traits, but showed some genetic antagonism with AFE. Puberty traits had negative genetic correlations with OR of NE and were poorly correlated with ES.

\section{DISCUSSION}

Estimates of the between- or within-breed genetic variability of sexual maturity traits are not very numerous in the literature. Moreover, available estimates generally have a low accuracy. This is likely due to the fact that puberty attainment is very tedious to detect. However, the delayed puberty of LW gilts as compared to LF gilts and the earlier sexual maturity of crossbred gilts as compared to pure breeds in the present study is in agreement with most other results in the literature (Christenson, 1981; Hutchens et al, 1982; Legault and Caritez, 1983; Allrich et al, 1985; Irgang et al, 1992). Heterosis effects could not be estimated without bias in this study because the LW $\times$ LF reciprocal cross was lacking, so that heterosis and maternal effects were confounded. However, maternal effects on age at puberty are of limited importance (Christenson, 1981; Allrich et al, 1985), so that the deviation of $\mathrm{LW} \times \mathrm{LF}$ from the purebred average should be close to heterosis effects. Indeed, the value obtained does not differ much from the literature average $(-11.3$ days; Bidanel, 1988). The larger OR of $\mathrm{LW}$ as compared to $\mathrm{LF}$ and the intermediate position of crossbred LW $\times \mathrm{LF}$, as well as the lack of difference between purebreds for $\mathrm{NE}$ and the larger litter size of $\mathrm{LW} \times \mathrm{LF}$ gilts, also agree with results from the literature (see, for instance, the reviews of Bidanel, 1989, and Blasco et al, 1993a).

Heritability estimates for ADG, ABT, age at puberty, OR and NE are close to previous estimates of Legault and Gruand (1981) and to average literature values (Bidanel, 1989; Lamberson, 1990; Stewart and Schinckel, 1990; Blasco et al, 1993a; Ducos, 1994). Conversely, the value obtained for weight at puberty is larger than most literature estimates (Young et al, 1978; Hutchens et al, 1981). The heritability of ES is lower than the values reported by Johnson et al (1984), Neal et al (1989) or Gama et al (1991) in synthetic populations but, unlike Haley and Lee (1992), tends to show that some genetic variation for ES exists in a LW population. Common litter effects $\left(c^{2}\right)$ tend to be larger than usual literature values, particularly for ADG and $\mathrm{ABT}$. This is probably due to a partial confounding between birth litter and herd of origin (litters generally came from different herds), both of which have an effect on growth performance.

The strong genetic correlation between NE and ES agrees with the estimates obtained in the Nebraska experiment (Neal et al, 1989) and with estimates obtained in mice and rabbits (Clutter et al, 1990; Blasco et al, 1993b). Conversely, a much stronger association between OR and NE and a lower relationship between OR and ES than in most other studies at 30 days of gestation (Young et al, 1977), 50 days of gestation (Neal et al, 1989) or at birth (Young et al, 1978) is observed. This may be due to differences in the populations studied, but may also indicate that uterine competition tends to increase throughout gestation. This increased competition has been evidenced by superovulation and embryo transfer experiments (Dziuk, 
1968; Pope et al, 1972; Webel and Dziuk, 1974) or more recently by experiments on unilaterally hystero-ovariectomized females (Christenson et al, 1987; Legault et al, 1995). Bennett and Leymaster (1989) proposed a model for litter size with two independent components, OR and uterine capacity, defined as the maximum number of fetuses that the uterine environment can support. In this model, OR is uncorrelated with ES and negatively correlated with fetal survival. The results from the present study are in fairly good agreement with this model, even if the small negative correlation between OR and ES might indicate that uterine capacity could also have some effect during early gestation. Similar results, ie, a low correlation between OR and ES and a much stronger one between OR and fetal survival, were obtained in intact (Blasco et al, 1993a) and unilaterally overiectomized does (Blasco et al, unpublished results), where a laparoscopic technique makes it possible to count rabbit fetuses during gestation with no detectable impact on subsequent fetal survival (Santacreu et al, 1990).

The large phenotypic and genetic correlations between age and weight at puberty are in close agreement with most available literature estimates (Reutzel and Sumption, 1968; Young et al, 1978; Hutchens et al, 1981). However, in spite of their close genetic relationship, age and weight at puberty show rather different correlations with growth rate. Indeed, negative relationships with age at puberty and positive ones with weight at puberty were obtained in all available studies (Reutzel and Sumption, 1968; Young et al, 1978, Hutchens et al, 1981, Rydhmer et al, 1992). This difference can be explained by noting that the correlation between growth rate and weight at puberty is the result of two antagonistic relationships, ie, a slight negative relationship between growth rate and age at puberty and a rather strong positive one between growth rate and weight at a given age. The relationships between puberty traits and backfat thickness are less clear. Negative, ie, unfavourable, genetic correlations with age at puberty were obtained by Gama and Johnson (1992), Rydhmer et al (1992) and in the present study. Conversely, null or positive correlations were reported by Young et al (1978), Hutchens et al (1981) and Hixon et al (1987). These discrepancies are partly due to the low accuracy of most estimates but may also, as argued by Rydhmer et al (1992), be due to genotype $\times$ feeding regime interactions between studies.

The negative, ie, favourable, genetic correlations between age at puberty and ovulation rate or number of embryos are consistent with the estimates obtained by Young et al (1978). Conversely, Rydhmer et al (1992) obtained positive genetic correlations between age at puberty and litter size at birth. These discrepancies may partly be due to differences in the traits analyzed (litter size at 30 days of gestation versus at birth). It may also be related to the fact that litter size was measured at a constant chronological age in the study of Rydhmer et al (1992), but at a constant physiological age in Young et al (1978) and in the present study (second and first estrus, respectively). However, a negative correlation is more likely to occur between age at puberty and litter size at a constant chronological age in young gilts, as prolificacy increases with estrus number. Thus late maturing gilts, which have a lower estrus number, would tend to have small litters (Rydhmer et al, 1992). The results of Després et al (1992), who found a decrease in age at puberty in the so-called 'hyperprolific' LW line selected for litter size in France, also tend to show that age at puberty is negatively correlated with sow prolificacy. 
In any case, results from the present study tend to indicate that selection for growth rate has an opposite effect to selection against backfat thickness on age and weight at puberty in the LW population studied. As a consequence, the correlated response of sexual maturity traits to selection on an index based on growth rate and backfat thickness will depend on the relative emphasis given to each trait in the selection index. A slight increase of both age and weight at puberty can be predicted from the index used and the genetic parameter estimates from the present study. Selection objectives in France have until now put a stronger emphasis on carcass lean content than on growth rate. Hence, a delayed sexual maturity may be expected based on the genetic parameters of the present study, provided that the genetic parameters obtained from these fairly old data are still valid for current pig populations. This delayed puberty may be accompanied by a reduced intensity of estrus symptoms, as recently shown by Rydhmer et al (1994). However, selection objectives in pigs are currently changing towards a lower emphasis on lean content and a stronger one on growth rate and prolificacy. A more favourable genetic trend for age at puberty can be expected from an increased economic weight of growth rate. Conversely, the impact of the growing economic weight of prolificacy remains unclear, because its relationship with age at puberty is not well established.

\section{CONCLUSION}

This study confirms that puberty traits are not genetically independent of production traits in gilts. As a consequence, age at puberty can be changed by selection for growth rate or carcass lean content. Favourable genetic trends can be expected from selection for growth rate, but unfavourable changes should result from selection for lean content. The evolution of puberty traits in pig breeding programs will therefore depend on the relative emphases placed on these traits, but also on other economically important traits such as food conversion ratio, meat quality or prolificacy. This study also provides genetic parameter estimates of components of litter size at 30 days of gestation, ie, ovulation rate and embryo survival. It tends to confirm the existence of some genetic variation in embryo survival, which is almost independent of genetic variation in ovulation rate.

\section{REFERENCES}

Allrich RD, Christenson RK, Ford JJ (1995) Age at puberty and estrous activity of straightbred and reciprocal crossed gilts. Anim Reprod Sci 8, 281-286

Bennett GL, Leymaster KA (1989) Integration of ovulation rate, potential embryonic viability and uterine capacity into a model of litter size in swine. J Anim Sci 67, 12301241

Bidanel JP (1988) Bases zootechniques et génétiques de l'utilisation en élevage intensif des races prolifiques chinoises - cas du porc Meishan. PhD thesis, Institut national agronomique, Paris-Grignon, France

Bidanel JP (1989) Taux d'ovulation et survie prénatale chez le porc : aspects génétiques. INRA Prod Anim 2, 159-170

Blasco A, Bidanel JP, Bolet G, Haley CS, Santacreu MA (1993a) The genetics of prenatal survival of pigs and rabbits: a review. Livest Prod Sci 37, 1-21 
Blasco A, Santacreu MA, Thompson R, Haley CS (1993b) Estimates of genetic parameters for ovulation rate, prenatal survival and litter size in rabbits from an elliptical selection experiment. Livest Prod Sci 34, 163-174

Bolet G, Ollivier L, Dando P (1989) Sélection sur la prolificité chez le porc. I. Résultats d'une expérience de sélection sur onze générations. Genet Sel Evol 21, 93-106

Christenson RK (1981) Influence of confinement and season of the year on puberty and estrous activity of gilts. J Anim Sci 52, 821-830

Christenson RK, Leymaster KA, Young LD (1987) Justification of unilateral hysterectomy-ovariectomy as a model to evaluate uterine capacity in swine. J Anim Sci 65, 738-744

Clutter AC, Nielsen MK, Johnson RK (1990) Alternative methods of selection for litter size in indice. I. Characterization of base population and development of methods. $J$ Anim Sci 68, 3536-3542

Cunningham PJ, England ME, Young LD, Zimmerman DR (1979) Selection for ovulation rate in swine: correlation response in litter size and weight. J Anim Sci 48, 509-516

Després P, Martinat-Botté F, Lagant H, Terqui M, Legault C (1992) Comparaison des performances de reproduction des truies appartenant à trois génotypes : Large White (LW), Large White «Hyperprolifique» (LWH), Meishan (MS). In: $24^{e}$ Journées Rech Porcine en France, Paris, 4-6 février 1990, Institut technique du porc, Paris, $25-30$

Ducos A (1994) Évaluation génétique des porcs contrôlés dans les stations publiques à l'aide d'un modèle animal multicaractère. $\mathrm{PhD}$ Thesis, Institut national agronomique, Paris-Grignon, France

Dziuk PJ (1968) Effect of number of embryos and uterine space on embryo survival in the pig. J Anim Sci 27,673-676

Gama LT, Boldman KG, Johnson RK (1991) Estimates of genetic parameters for direct and maternal effects on embryonic survival in swine. J Anim Sci 69, 4801-4809

Gama LT, Johnson RK (1992) Correlated responses to selection for prolificacy or age at puberty in pigs. In: 43rd Annual Meeting of the EAAP, Madrid, Spain, September 1992, Commission on Animal Genetics

Groeneveld E (1993) Estimating (co)variances for joint genetic evaluations. In: Proc EC Seminar on Application of Mixed Linear Models in the Prediction of Genetic Merit in Pigs (E Groeneveld, ed), IAHAE-FAL, Mariensee, Germany, 83-102

Groeneveld E, Kovac M (1990) A generalized computing procedure for setting up and solving mixed linear models. J Dairy Sci 73, 513-531

Haley CS, Lee GJ (1992) Genetic factors contributing to variation in litter size in British Large White gilts. Livest Prod Sci 30, 99-113

Henderson CR (1973) Sire evaluation and genetic trends. In: Proc Animal Breeding and genetics Symposium in honor of Dr JL Lush, American Society of Animal Science and Dairy Science Association, Champaign, IL, 10-41

Hixon AL, Mabry JW, Benyshek LL, Weaver WM, Marks MA (1987) Estimates of genetic parameters for sexual and compositional maturity in gilts. J Anim Sci 64, 977-982

Hutchens LK, Hintz RL, Johnson RK (1981) Genetic and phenotypic relationships between puberal and growth characteristics of gilts. J Anim Sci 53, 946-951

Hutchens LK, Hintz RL, Johnson RK (1982) Breed comparisons for age and weight at puberty in gilts. J Anim Sci 55, 60-66

Irgang R, Scheid IR, Favero JA, Wentz I (1992) Daily gain and age and weight at puberty in purebred and crossbred Duroc, Landrace and Large White gilts. Livest Prod Sci 32, $31-40$

Johnson RK, Zimmerman DR, Kittok RJ (1984) Selection for components of reproduction in swine. Livest Prod Sci 11, 541-558 
Lamberson WR (1990) Genetic parameters for reproductive traits. In: Genetics of Swine 70-76

Lamberson WR, Johnson RK, Zimmerman DR, Long TE (1991) Direct responses to selection for increased litter size decreased age at puberty, or random selection following selection for ovulation rate in swine. J Anim Sci 69, 3129-3143

Legault C (1973) Déterminisme génétique de la précocité sexuelle, du taux d'ovulation, et du nombre d'embryons chez la truie primipare: héritabilité, effet d'hétérosis. In: $5^{e}$ Journées Rech Porcine en France, Paris, 14-16 février 1973, Institut technique du porc, Paris, 347-354

Legault C, Gruand J (1981) Effets additifs et non additifs des gènes sur la précocité sexuelle, le taux d'ovulation et la mortalité embryonnaire chez la jeune truie. In: $13^{e}$ Journées Rech Porcine en France, Paris, 4-5 février 1981, Institut technique du porc, Paris, 247-254

Legault C, Caritez JC (1983) L'expérimentation sur le porc chinois en France. I. Performances de reproduction en race pure et en croisement. Génét Sél Evol 15, 225-240

Legault C, Caritez JC, Lagant H, Popescu P (1995) Étude expérimentale du rôle de l'espace utérin sur la viabilité embryonnaire et foetale. Incidence du type génétique de la mère. In: 2łe Journées Rech Porcine en France, Paris, 31 janvier-2 février 1995, Institut technique du porc, Paris, 25-30

Neal SM, Johnson RK, Kittok RJ (1989) Index selection for components of litter size in swine: response to five generations of selection. J Anim Sci $67,1933-1945$

Ollivier L (1977) Dix ans d'une expérience de sélection individuelle sur des verrats utilisés en insémination artificielle. I. Réponses observées sur des caractères de croissance, de carcasse et de qualité de viande. Ann Génét Sél Anim 9, 353-377

Ollivier L (1980) Estimated responses to eleven years of boar selection. Livest Prod Sci 7 , $57-66$

Ollivier L, Guéblez R, Webb AJ, Van Der Steen HAM (1990) Breeding goals for nationally and internationally operating pig breeding organisations. In: 4th World Congress on Genetics Applied to Livestock Production, Edinburgh, 23-27 July, 15, 383-394

Pope CE, Christenson RK, Zimmerman-Pope VA, Day BN (1972) Effect of number of embryos on embryonic survival in recipient gilts. J Anim Sci 35, 805-808

Reutzel LF, Sumption LJ (1968) Genetic and phenotypic relationships involving age at puberty and growth rate of gilts. J Anim Sci 27, 27-30

Rydhmer L (1993) Pig reproductive genetics and correlations between reproduction and production traits. PhD thesis, Swedish University of Agricultural Sciences, Uppsala, Sweden

Rydhmer L, Johansson K, Stern S, Eliasson-Selling L (1992) A genetic study of pubertal age, litter traits, weight loss during lactation and relations to growth and leanness in gilts. Acta Agric Scand 42, 211-219

Rydhmer I, Eliasson-Selling L, Johansson K, Stern S, Andersson K (1994) A genetic study of estrus, symptoms at puberty and their relationship to growth and leanness in gilts. J Anim Sci 72, 1964-1970

Santacreu MA, Gou P, Blasco A (1990) Évaluation par cœlioscopie des corps jaunes et des embryons. Influence sur la taille de la portée chez la lapine. Reprod Nutr Dev 30, 583-588

Stewart TS, Schinckel AP (1990) Genetic parameters for swine growth and carcass traits. In: Genetics of Swine (LD Young, ed), USDA, ARS-MARC, Clay Center, NE, 84-87

Tess MW, Bennett GL, Dickerson GE (1983) Simulation of genetic changes in life cycle efficiency of pork production. II. Effects of components on efficiency. J Anim Sci 56, 354-368 
Webel SK, Dziuk PJ (1974) Effect of stage of gestation and uterine space on prenatal survival in the pig. J Anim Sci 38, 960-963

Young LD, Johnson RK, Omtvedt IT (1977) An analysis of the dependency structure between a gilt's prebreeding and reproductive traits. I. Phenotypic and genetic correlations. J Anim Sci 44, 557-564

Young LD, Pumfrey RA, Cunningham PJ, Zimmerman DR (1978) Heritabilities and genetic and phenotypic correlations for prebreeding traits, reproductive traits and principal components. J Anim Sci 46, 937-949 